Catocala irene Behr.

Ovum. Similar to that of C. californica and faustina.

Stage I. Scarcely to be distinguished from faustina; head pale red-brown; body greenish-gray shading into purplish laterally with three pale lines of ground color. Length, $5 \mathrm{~mm}$.

Stage II. Head whitish, marbled with blackish stripes, with slight tinge of orange apically. Body pale gray-green, laterally greenish-black with three pale waved stripes; a faint dorsal stripe with diamond-shaped enlargements. Length, $11 \mathrm{~mm}$.

Stage III. Head pale with brown marbling, shaded with orange at apex and with black lateral border-lines not meeting dorsally. Body light olive-brown with pale dorsal and lateral stripes as before bordered with deep brown, the lower border of stripe II and the upper one of III especially prominent; transverse wart on 5th abdominal segment reddish with ochreous apex; below the wart a blackbrown lateral shade broken by the pale stripes, deepest in color above stripe III and tending to extend along its dorsal margin towards anal segment; dorsal tubercles orange, larger and conical on 8th abdominal segment with slight black lunate marks behind them not meeting dorsally. Length, $17 \mathrm{~mm}$.

Food-plant: Willow.

We were unsuccessful in bringing the larvæ to maturity. They are evidently also allied closely to faustina.

\title{
THE DISTRIBUTION OF SOME SPECIES OF DROSOPHILA.
}

\author{
By Charles W. Johnson, \\ Boston Society of Natural History, Boston, Mass.
}

In making a careful faunal survey of any given area, covering a number of years, the gradual or sudden appearance of a species common in other sections, is often of greater importance from the standpoint of geographical distribution than the capture of a number of rare species, often widely distributed, but of whose life history or of the factors governing their distribution little is known.

During the early fall, while experimenting with various species of fungi in an effort to breed some Platypezidæ, my attention was called to several dark colored flies which alighted repeatedly on the netting of many of the jars containing decayed fungi. On capturing several of these I was surprised to see Drosophila repleta Woll. (D. punctata Loew), the first I had seen in Boston. I had 
taken several specimens of this Southern species in Philadelphia, in 1898, had received it from Providence, R. I., in 1904 and from Fall River, Mass., in 1905. Recently Dr. E. P. Felt recorded the species as having been taken in New York City and also at Albany in September and October, 1908.

Another species which appeared later (October 15-20) in large numbers in the same jars of fungi, was D. busckii Coq., a species described from the District of Columbia, West Virginia and Illinois in 1901. In $1908 \mathrm{Mr}$. Wm. Reiff obtained this species from his breeding cages at Forest Hills, Mass., and in 1912, Mr. P. W. Whiting also obtained it at the same locality on decayed meat, while breeding Lucilia.

It seems hardly possible that these social flies could have escaped detection if they had been here in numbers for any length of time, nor is it likely that they have been introduced suddenly by commerce, although the fruit trade may have aided in the wide distribution of D. repleta throughout the United States, as recorded by Mr. Frederick Knab in Psyche Vol. XIX, June, 1912.

The corresponding distribution of $D$. repleta and D. melanogaster Meig. (D. ampelophila Loew) and the fact that in America both were first described from Cuba, seem to point conclusively to similar lines of dispersal. In 1862, Loew described $D$. ampelophila and in a note says: "Drosophila ampelophila is very frequent in the Southern regions of Europe, nor is it entirely wanting to middle Europe; it also inhabits the Southern parts of Africa." [Translation.]

Meigen in 1830 had described the form with blackish abdomen from Europe as D. melanogaster and the same form was described by Zetterstedt in 1847 as $D$. nigriventris. In 1875 , Rondani described the yellow form from Italy as $D$. uvarum.

From the time of Loew's description in 1862 until about 1879, there seems to be no record in America bearing positively on this species. Then a number of articles were published indicating that their appearance in great numbers was evidently not a common occurrence. In the Canadian Entomologist, Vol. 14, p. 101, 1882, G. G. Bowles of Montreal says: "In August of 1879, I met with a small dipterous fly, Drosophila ampelophila Loew, in considerable numbers." In the same Journal, page 138, 1882, Dr. W. S. Williston says: "In the Autumn of 1879, I bred and recognized 
numerous specimens of Drosophila ampelophila Loew, at New Haven, from decaying pears, and labelled specimens bearing date of October 30. Since then I have observed them in August, September and October in the greatest abundance in Massachusetts and Connecticut." After quoting the above note by Loew on its distribution he says: "The question is an interesting one: In which continent is it a native?"

Lintner, in his first annual report, 1882, page 216, says, in referring to some small flies that were sent to him, "They proved to be identical with numerous specimens of Drosophila ampelophila in my collection, having the memorandum of "bred from a jar of pickled plums, September, 1875." Comstock, in the Report of the Department of Agriculture 1881-1882, describes and figures its life history.

The question to be considered now is, did this species occur in the Northern States during Say's, Harris' or Fitch's time, or has it worked northward since then? Say might have overlooked it, but for Harris, and especially Fitch-who described so many minute diptera, to have entirely ignored this species, seems improbable.

To return to $D$. repleta whose dispersal throughout the United States is so fully recorded. This was described by Loew from Cuba in 1862 as D. punctulata. It had, however, been previously described from Madeira by Wollaston in 1858. In 1886, Mik described the same species as D. aspersa from Vienna, Austria and Ashanti, W. Africa. The more gradual and recent dispersal of $D$. repleta would indicate that it was not indigenous to America and that it undoubtedly appeared first in the West Indies. There is no evidence to dispute the fact that $D$. melanogaster might also have appeared first in the West Indies and being more prolific, has spread with greater rapidity.

I think we can thus reasonably consider the Eastern Continent as the original habitat of the two species and that they have been introduced either by vessels sailing from Southern Europe during the Spanish régime or from Western Africa during the slave trade. There is another fly that is supposed to have been introduced in this manner. Osten Sacken, in describing Borborus venalicius (Cat. of Diptera, p. 263, 1878), from Cuba, says: "Dr. Loew informs me that this is an African species; and as I found it abun- 
dantly in Cuba, it seems probable that it was brought over in slave ships." This species has also spread northward into Florida and Bermuda and southward to Brazil.

\section{NOTE ON TWO PREOCCUPIED MUSCID NAMES.}

In the April issue of Psyche I published a synopsis of the Sapromyzidæ in which on page 58 was described a new genus of Sciomyzidæ under the name Poecilomyia. Hendel (Genera Insectorum, Richardiinæ, p. 24, 1911), has previously used this name, hence I propose to change it to Poecilographa. In the same paper, on page 73, I described a Minettia annulata, overlooking Becker's Lauxania annulata (Ztschr. Hym. Dipt., 1907, 383). In as much as the present tendency is to consider Minettia as a subgenus of Lauxania the preoccupied name may be changed to annularis.

A. L. Melander.

\section{BOOK REVIEW.}

Seitz, Adalbert. The Macrolepidoptera of the World. To be completed in 16 volumes containing about 485 parts, of which two complete volumes and numerous parts have been issued. Stuttgart, Verlag des Seitzschen Werkes (Alfred Kernen) 1906.

This elaborate compendium of the larger Lepidoptera, undertaken by Professor Seitz in 1906, has now reached the stage that its completion within a reasonable time seems to be assured. A large number of fascicles have been issued by Seitz and his various collaborators, who include, Aurivillius Bartel, Eiffinger, Fruhstorfer, Grünberg, Haensch, Janet, Jordan, Mabille, Pfitzner, Prout, Röber, Rothschild, Standfuss, South, Strand, Warren and Weymer.

The main feature of the work is a large series of beautifully executed, colored plates, which according to estimate will number about one thousand in the completed set. All which the reviewer has seen are of very exceptional quality in spite of the low price at which they are sold. The letter-press includes descriptions of genera and higher groups as well as of species and these seem on the whole to be fairly complete, although occasionally the specific descriptions drift into a running commentary on the illustrations. Considering, however, the enormous mass of material to be dealt with, the authors are to be congratulated on avoiding this latter condition to a very great extent. Taken together, the text and figures should make it a comparatively simple matter for any one to identify a large proportion of the species that are described and figured. To facilitate this process, the faunæ of the different zoölogical regions have been grouped into four independent series dealing with the Palæarctic, American, Indo-australian and African faunæ respectively. Each is to be complete in itself as a set of four volumes and an additional 17th volume to contain general matter on structure, biology and distribution is promised.

Lepidopterists as well as amateur collectors throughout the world will be very fortunate to have such a generally complete cyclopædic account of the larger butterflies and moths.

C. T. B. 

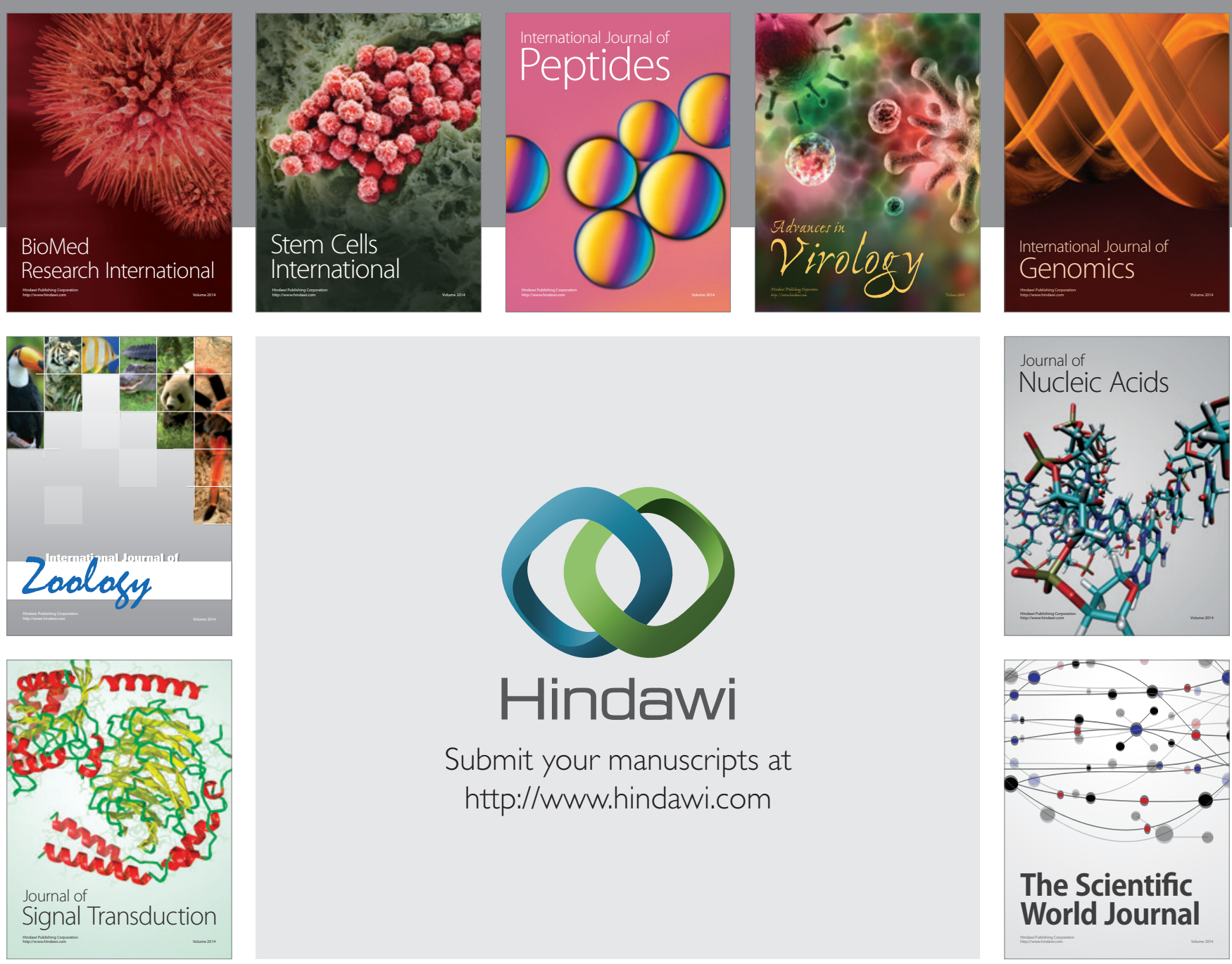

Submit your manuscripts at

http://www.hindawi.com
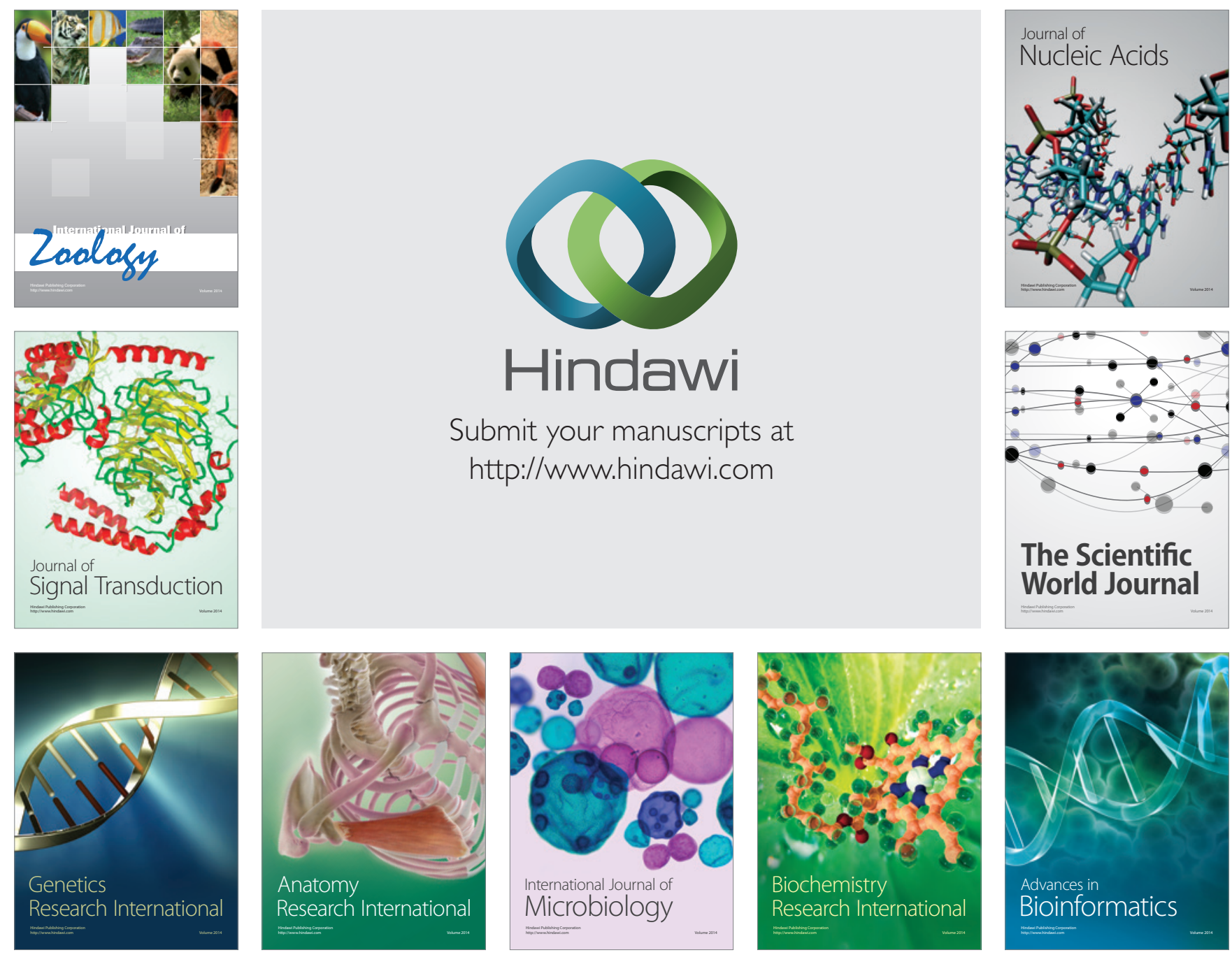

The Scientific World Journal
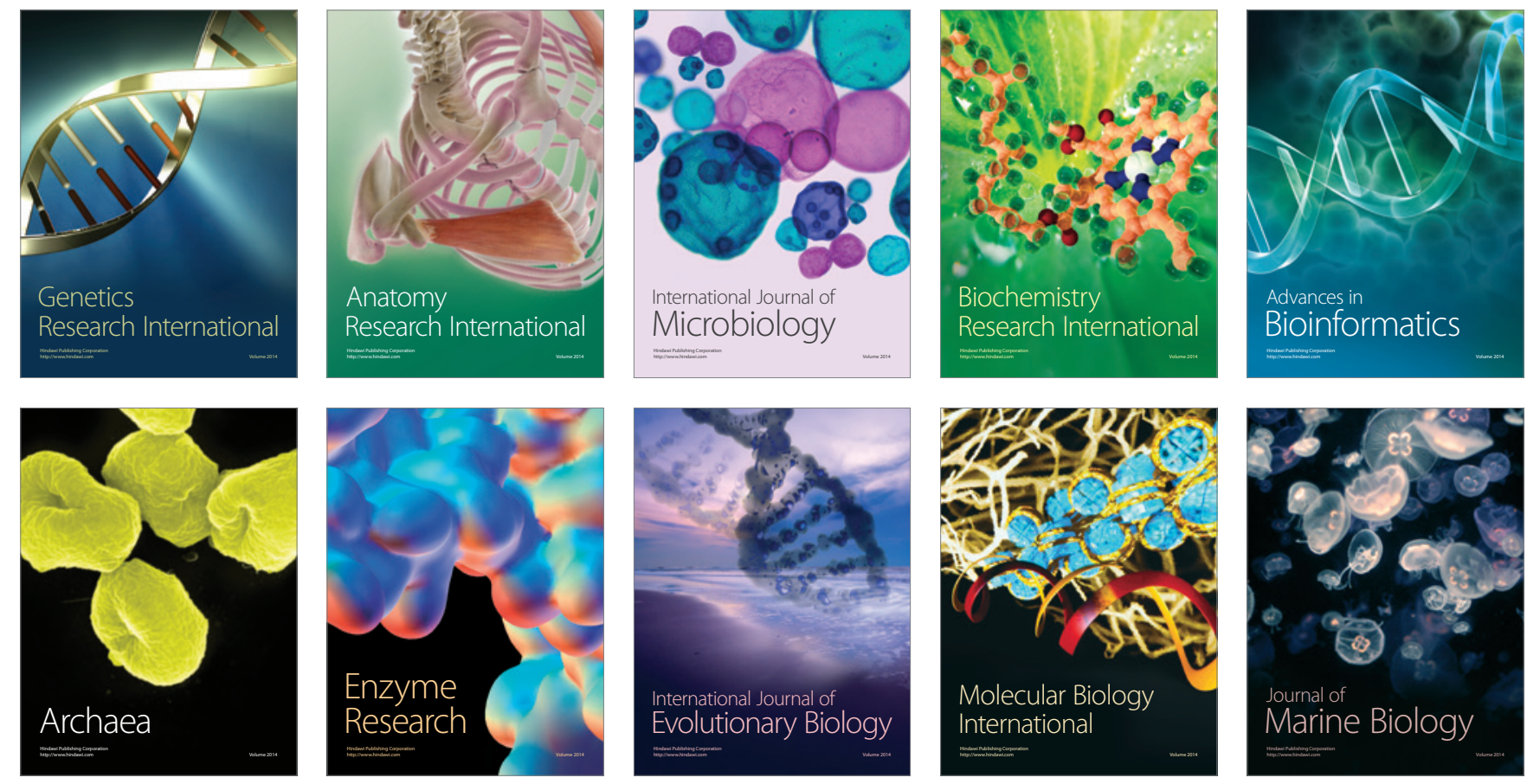